\title{
Chemická zonálnost' Ti-andraditového granátu v Ca-skarne z oblasti Magnetový vrch pri Tisovci (Slovenská republika)
}

\author{
Chemical zoning of Ti-andradite garnet in Ca-skarn from the Magnet hill area \\ near Tisovec (Slovak Republic)
}

\author{
Peter RužıčKa ${ }^{1) *}$, Pavol MyšL'an ${ }^{1)}$, Martin Števkoo ${ }^{2,3)}$ a Sergil Kurylo( ${ }^{4)}$ \\ 1)Katedra mineralógie, petrológie a ložiskovej geológie, Prírodovedecká fakulta, Univerzita Komenského v Bratislave, \\ Ilkovičova 6, Mlynská dolina, 84215 Bratislava, Slovenská republika; *e-mail: peter.ruzicka@uniba.sk \\ 2) Ústav vied o Zemi, Slovenská akadémia vied, Dúbravská cesta 9, 84005 Bratislava, Slovenská republika \\ ${ }^{3)}$ Mineralogicko-petrologické oddělení, Národní muzeum, Cirkusová 1740, 19300 Praha 9 - Horní Počernice, \\ Česká republika \\ 4)Ústav vied o Zemi, Slovenská akadémia vied, Ďumbierska 1, 97411 Banská Bystrica, Slovenská republika
}

RužIČKA P, MYŠĹAN P, ŠTEVKo M, KuRYLo S (2021) Chemická zonálnost' Ti-andraditového granátu v Ca-skarne z oblasti Magnetový vrch pri Tisovci (Slovenská republika). Bull Mineral Petrolog 29(1): 49-58 ISSN 2570-7337

\begin{abstract}
Analyzed garnets from the Magnet hill area near Tisovec (Slovak Republic) are part of a Ca-skarn mineral association consisting of diopside, clinochlore and calcite. Compositionally they correspond to Ti-rich andradite $\left(\operatorname{Adr}_{50.9-73.7}\right)$ with minor grossular $\left(\mathrm{Grs}_{3.8-44.5}\right)$ and schorlomite $\left(\mathrm{Sch}_{0.5-41.5}\right)$ components. Garnets contain up to 13 wt. \% $\mathrm{TiO}_{2}$ and in all of them ${ }^{\mathrm{Y}} \mathrm{Fe}^{3+}>\mathrm{Y} \mathrm{Ti}$ ratio prevails. Both sector and oscillatory chemical zoning were observed, which is primarily caused by variable distribution of $\mathrm{Ti}$ contents within individual garnet crystals. The three principal zones were distinguished in BSE imaging. The brightest are Ti-enriched zones with Ti content ranging from 0.85 to 0.50 apfu. Titanium gradually decreases in transitional zone (0.17 - $0.40 \mathrm{apfu})$ and reaches the minimum values in the dark zones $(0.01-0.13 \mathrm{apfu})$. In the Ti-enriched zones the content of $\mathrm{Si}^{4+}$ and $\mathrm{Al}^{3+}$ is decreased due to substitution of $\mathrm{Ti}^{4+}$ and $\mathrm{Fe}^{3+}$ and assumed hydrogarnet substitution $\left(\mathrm{SiO}_{4}\right)^{4-} \leftrightarrow\left(\mathrm{O}_{4} \mathrm{H}_{4}\right)^{4-}$.
\end{abstract}

Key words: Ti-andradite, Ca-skarn, Magnet hill, Tisovec, Slovak Republic

Obdrženo 8. 12. 2020; prijiato 3. 5. 2021

\section{Úvod}

Granáty vznikajúce metasomatickými účinkami kontaktnej metamorfózy často prejavujú rôzne formy zonálnosti, ktorá je spojená s distribúciou prvkov počas ich rastu. Prejavy zonálnosti v granátoch odrážajú variabilitu obsahov koncových a prechodných členov granátovej superskupiny $v$ kontexte genetických procesov (Jamtveit et al. 1995; Ivanova et al. 1998; Agrosi et al. 2002; Grew et al. 2013; Zhai et al. 2014; Antao et al. 2015; Park et al. 2017).

Objektom nášho detailného mineralogického štúdia boli granáty $\mathrm{s}$ obsahom $\mathrm{Ti}$, ktoré tvoria lokálne polohy $\mathrm{v}$ Ca-skarne v oblasti Magnetového vrchu pri Tisovci. Tieto granáty disponujú rôznymi prejavmi chemickej zonálnosti. Zamerali sme sa na výskum ich chemického zloženia s ciel'om kvantifikácie distribúcie Ti v granátoch.

\section{Lokalizácia a geologická charakteristika}

Skúmané územie v oblasti kóty Magnet (964 m n. m.) je situované cca $5 \mathrm{~km}$ severozápadne od mesta Tisovec v okrese Rimavská Sobota (obr. 1a). Tvorí súčast' Slovenského rudohoria $v$ rámci celku Veporské vrchy s podcelkom Fabova hol'a (Mazúr, Lukniš 1980). Študovaná lokalita sa nachádza na sv. svahu kóty Pacherka (960 m n. m.). Vzorky Ca-skarnov, v ktorých sú zastúpené skú- mané granáty, pochádzajú zo skalného odkryvu, ktorý vzhl'adom na mieru zasutenia dosahuje rozmery cca $5 \times$ $2 \mathrm{~m}$ (obr. 1b). GPS súradnice odkryvu sú $48^{\circ} 42^{\prime} 39.8^{\prime \prime} \mathrm{N}$ a $19^{\circ} 54^{\prime} 08.3^{\prime \prime E ~ s ~ n a d m o r s k o u ~ v y ́ s ̌ k o u ~} 747 \mathrm{~m}$.

Prevažnú čast' skúmaného územia tvoria paleozoické granodiority až granity král'ovohol'skej zóny kryštalinika veporika a mezozoické karbonátové horniny Muránskeho krasu silicika modelované tektonickými a erozívno-denudačnými procesmi s vulkanickou aktivitou v neogéne (obr. 2). V kenozoiku prebiehal výzdvih veporika a peneplenizácia územia s denudáciou povrchovej stavby veporského stratovulkánu s výnimkou zvyškov výplne pôvodných paleodolín. Denudačným zrezom bol pravdepodobne obnažený subvulkanický intruzívny komplex Magnetový vrch (Konečný et al. 2011, 2015). Relikty neogénneho vulkanizmu boli identifikované počas geologického mapovania územia (Bacsó 1964; Klinec 1976; Vojtko 2000; Konečný et al. 2001, 2011, 2015). Intruzívny dioritový komplex Magnetový vrch centrálnej vulkanickej zóny datovaný K/Ar metódou má vek $12 \pm 1.0 \mathrm{Ma}$ (Konečný et al. 2011, 2015).

Prvýkrát prejavy kontaktných účinkov dioritovej magmy na okolité horniny $v$ oblasti Magnetový vrch opísal Junghann (1912), čo neskôr potvrdili Adam et al. (1956). Miocénne diority a andezity $v$ tektonicky oslabených zónach prerazením granitoidov veporika a prenikom cez 

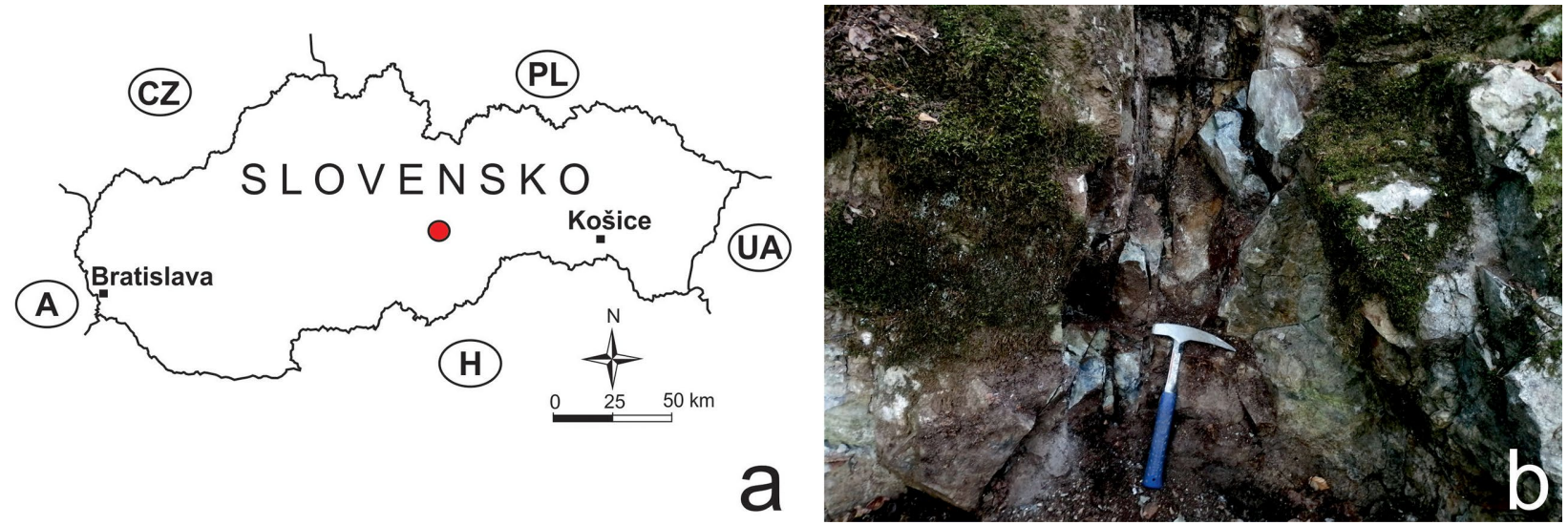

Obr. 1 Lokalizácia skúmaného územia: a) v mape SR; b) detail miesta odberu vzoriek. Foto P. Ružička 2020.

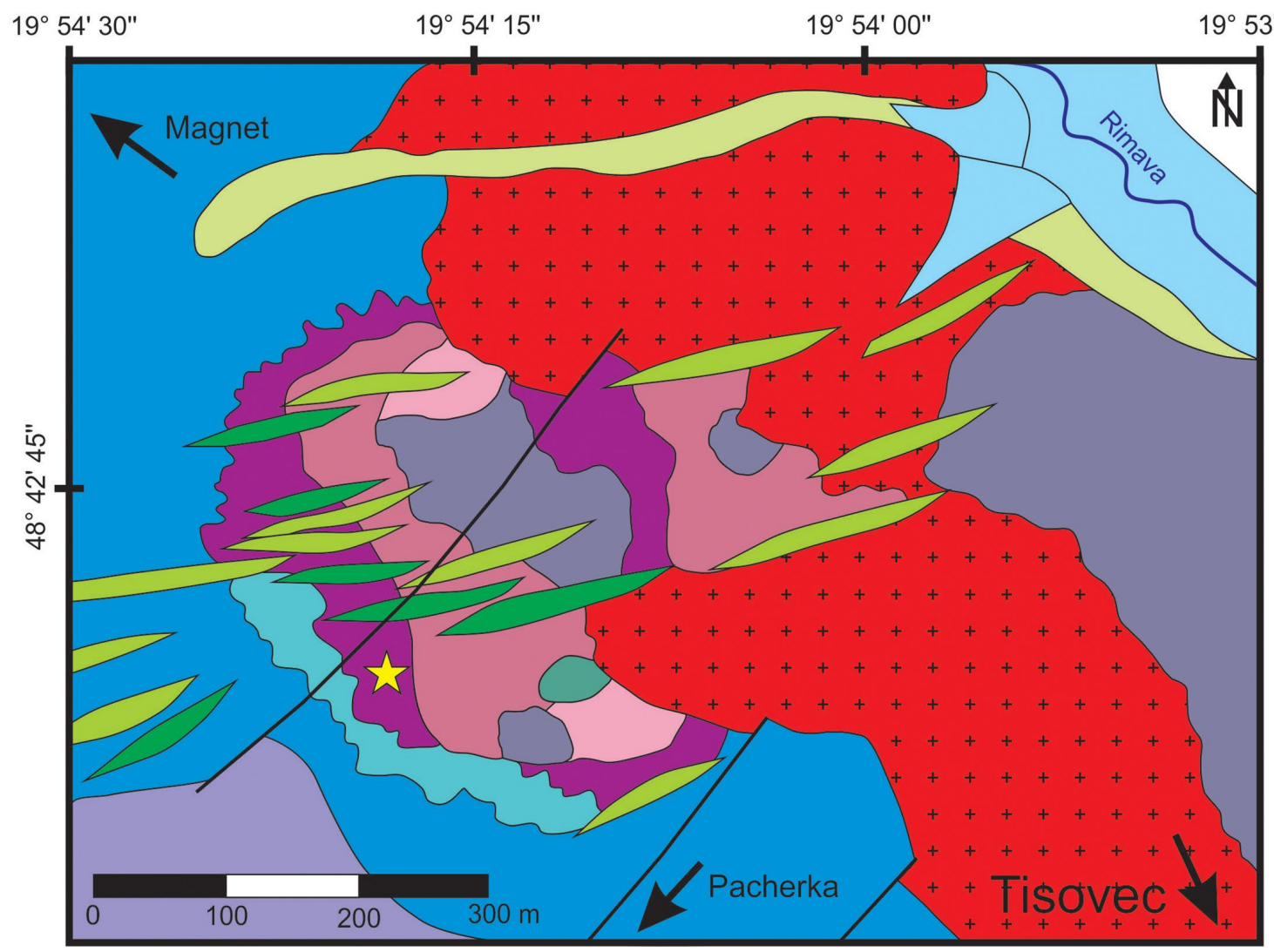

\section{Silicikum (trias)}

a) aluviálne; b) deluviálne sedimenty

\section{Intruzívny komplex Magnetový vrch}

a dajky: a) dioritov; b) andezitov

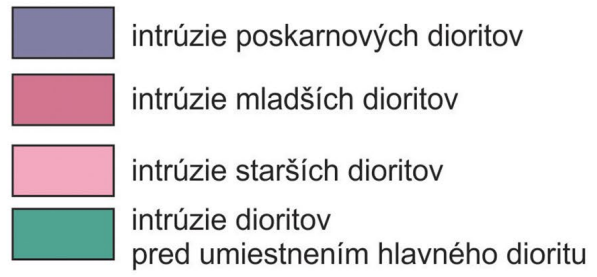

$\square$ wettersteinské dolomity
$\square$ wettersteinské vápence

Kryštalinikum južného veporika (devón? - karbón)

++ granodiority až granity

Všeobecné vysvetlivky

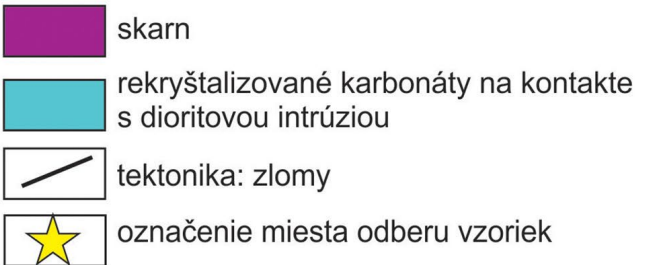

Obr. 2 Zjednodušená geologická mapa s detailom skúmanej lokality v mierke 1: 10000 podl’a Konečný et al. (2011, 2015). 
muránsky príkrov silicika kontaktnými účinkami iniciovali vznik skarnov s lokálnymi prejavmi polymetalickej mineralizácie počas prebiehajúcej rekryštalizácie triasových karbonátov. Bacsó $(1959,1964,1973)$ podrobne charakterizoval jednotlivé vývojové štádiá skarnovej mineralizácie v oblasti Magnetového vrchu.

Konečný et al. $(2001,2011,2015)$ vyčlenili 7 intruzívnych vývojových fáz subvulkanického intruzívneho komplexu Magnetový vrch s predpokladom, že metasomatické procesy iniciujúce vznik skarnov sa uplatnili počas 1. intruzívnej fázy a naložené hydrotermálne premeny počas 2. intruzívnej fázy.

\section{Metodika}

Terénny odber bol zameraný na získanie reprezentatívnych vzoriek Ca-skarnov v rámci skúmanej lokality, ktoré boli mikroskopicky študované vo výbrusoch pomocou polarizačného mikroskopu Leica DM2500P na Katedre mineralógie, petrológie a ložiskovej geológie Prírodovedeckej fakulty Univerzity Komenského v Bratislave.

Leštené výbrusy vzoriek, vákuovo naparené tenkou uhlíkovou vrstvou, boli analyzované na elektrónovom mikroanalyzátore JEOL JXA 8530F na Ústave vied o Zemi Slovenskej akadémie vied v Banskej Bystrici. Analyzovaných bolo 12 granátových zŕn pochádzajúcich z dvoch vzoriek Ca-skarnov (označenie TIS-1 a TIS-2) pri urýchl'ovacom napätí $15 \mathrm{kV}$ a prúde $20 \mathrm{nA}$. Priemer elektrónového lúča sa prispôsoboval počas merania silikátov na $3-5 \mu \mathrm{m}$ a pre kalcit $8 \mu \mathrm{m}$. Použila sa ZAF korekcia. Zonálnost' sa pozorovala v spätne rozptýlených elektrónoch (BSE). Na meranie fáz boli použité nasledovné štandardy: kremeň, ortoklas $(\mathrm{Si}, \mathrm{K}-\mathrm{K \alpha})$, rutil $(\mathrm{Ti}-\mathrm{K \alpha})$, albit $(\mathrm{Al}, \mathrm{Na}-K \alpha)$, hematit $(\mathrm{Fe}-K \alpha)$, rodonit $(\mathrm{Mn}-K \alpha)$, diopsid $(\mathrm{Mg}, \mathrm{Ca}-\mathrm{K} \alpha$ ). Elektrónové mikroanalýzy boli prepočítané v zmysle platných klasifikácií pre granáty (Grew et al. 2013) a pyroxény (Morimoto et al. 1988). Pomer $\mathrm{Fe}^{2+} / \mathrm{Fe}^{3+}$ bol vypočítaný z nábojovej bilancie.

\section{Výsledky}

\section{Chemické zloženie a zonálnost' granátov}

Skúmané granáty sa nepravidelne vyskytujú v masívnych, prevažne svetlozelených Ca-skarnoch, ktoré obsahujú makroskopicky viditel'né nepravidelné čierne škvrnité polohy tvorené magnetitom s akcesoricky prítomným chalkopyritom. Granáty sú súčast'ou minerálnej asociácie zastúpenej klinopyroxénmi, chloritmi a kalcitom

Ti-obohatené granáty majú hnedú farbu (obr. 3) a sú opticky izotropné. Tvoria individuálne idiomorfne obmedzené zrná s rozmermi do $0.5 \mathrm{~mm}$. V kryštáloch granátov je $v$ BSE zobrazení dobre pozorovatel'ná chemická zonálnost' s variabilným chemickým zložením. Vzhl'adom na stavbu a charakter chemickej zonálnosti granátov sme robili bodové mikroanalýzy na zachytenie výrazných kompozičných rozdielov $v$ jednotlivých zónach (BSE - svetlá, prechodná a tmavá) analyzovaných zŕn. Heterogénny charakter zonálnej stavby granátov sa prejavuje rôznou intenzitou a ohraničením kompozičného kontrastu jednotlivých zonálnych prechodov (obr. 4).

Svetlá zóna obsahuje najviac Ti (0.50 - 0.85 apfu) a $\mathrm{Al}(0.28-0.35$ apfu), pri najnižšom obsahu Si (2.22 - 2.55 $a p f u$ ). To má zásadný vplyv na zastúpenie koncových členov, čo sa prejavuje najvyšším podielom schorlomitovej zložky $\left(\operatorname{Sch}_{242-41.5}\right)$ voči prechodnej a tmavej zóne, za ktorou nasleduje podiel andraditovej zložky $\left(\operatorname{Adr}_{533-70.9}\right)$ a vel'mi nízky podiel grosulárovej zložky $\left(\mathrm{Grs}_{3.8-4.9}\right)$. Najnižší podiel má spessartínová zložka $\left(\mathrm{Sps}_{06-1.0}\right)$ a nulové hodnoty dosahujú pyropová a almandínová zložka (tab. 1, 2; obr. 5).

Prechodná zóna z hl'adiska obsahov Ti (0.17-0.40 apfu), Al (0.14-0.36 apfu) a Si (2.64 - 2.86 apfu) dosahujú stredný interval nameraných hodnôt. Z hl'adiska zastúpenia koncových členov klesá obsah schorlomitovej zložky $\left(S_{\text {ch-19.6 }}\right)$ na úkor stúpania obsahu andraditovej zložky $\left(\operatorname{Adr}_{54.6-73.7}\right)$, ako aj nárastu grosulárovej zložky $\left(\mathrm{Grs}_{6.6-35.9}\right)$. Mierne sa zvýšilo zastúpenie pyropovej zložky ( $\left.\operatorname{Prp}_{0.6-1.1}\right)$. Almandínová a spessartínová zložka majú nulové hodnoty (tab. 1, 2; obr. 5).

Tmavá zóna obsahuje najmenej Ti (0.01 - 0.13 apfu) a $\mathrm{Al}(0.01-0.11 \mathrm{apfu})$ a najviac Si $(2.89-2.99 \mathrm{apfu})$. Z hl'adiska zastúpenia koncových členov je $v$ tmavej zóne najnižší obsah schorlomitovej zložky $\left(\mathrm{Sch}_{0.5-6.2}\right)$, ktorý je kompenzovaný andraditovou zložkou ( $\operatorname{Adr}_{50.9-69.3}$ ) a najvyšším zastúpením grosulárovej zložky $v$ rámci vyčlenených zón $\left(\mathrm{Grs}_{28.4-44.5}\right)$. Okolo hodnoty $1 \mathrm{~mol}$. \% osciluje pyropová $\left(\operatorname{Prp}_{0.6-1.0}\right)$ a spessartínová $\left(\mathrm{Sps}_{0-0.9}\right)$ zložka. Almandínová zložka je konštantne na nulových hodnotách (tab. 1, 2; obr. 5).

$\mathrm{V}$ Ti-obohatených granátoch klesá obsah $\mathrm{Si}^{4+}$ aj $\mathrm{Al}^{3+}$ pretože sa substituujú za $\mathrm{Fe}^{3+}$ a $\mathrm{Ti}^{4+}$. Zmeny $v$ chemickom zložení sa výrazne prejavujú v lineárnom priebehu substitučného trendu $\mathrm{Ti}^{4+}$ verzus $\mathrm{Si}^{4+}$ (obr. $5 \mathrm{c}$ ). $V$ študova-
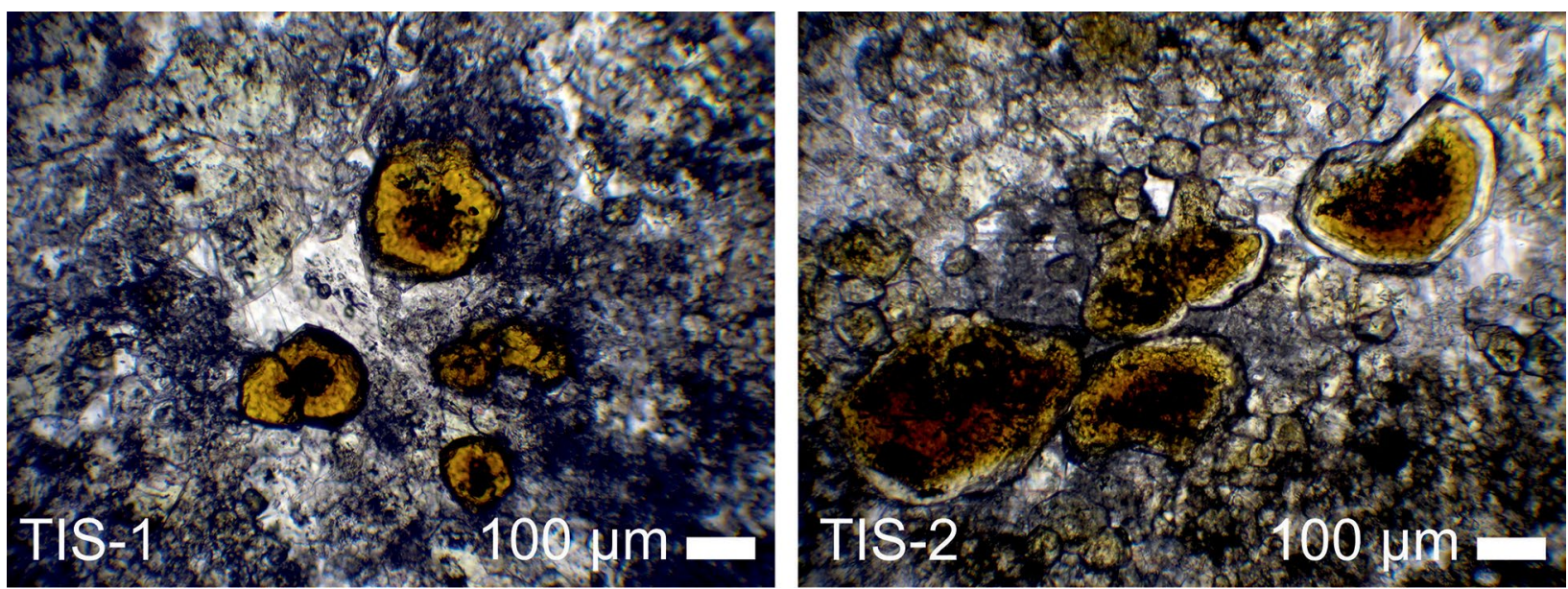

Obr. 3 Mikroskopické detaily Ti-andraditových granátov v Ca-skarne pri jednom nikole. Fotografie z polarizačného mikroskopu P. Ružička. 

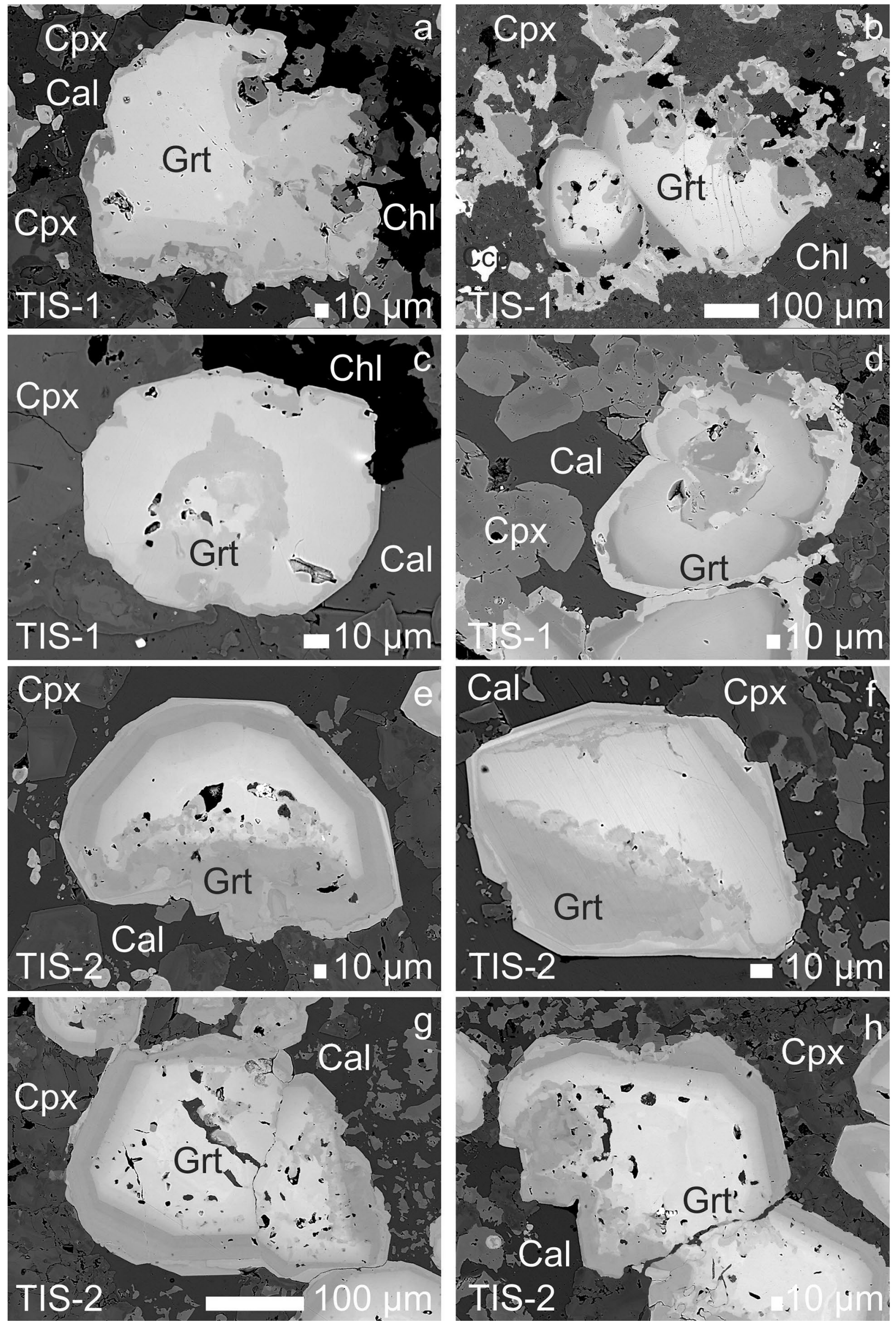

Obr. 4 Príklady zonálnosti granátov z Tisovca pozorované v režime BSE. Foto S. Kurylo. Význam použitých skratiek: Grt - granáty, Cpx - klinopyroxény, Chl - chlorit, Cal - kalcit, Ccp - chalkopyrit. 
Tabul'ka 1 Reprezentatívne mikrosondové analýzy granátov (hm. \%) vzorky TIS-1 v Ca-skarnoch prepočitané na 12 kyslíkov a 8 katiónov (apfu) s vyjadrením zastúpenia koncových členov (mol. \%).

\begin{tabular}{|c|c|c|c|c|c|c|c|c|c|c|c|c|}
\hline \multirow{3}{*}{$\begin{array}{l}\text { Vzorka } \\
\text { Granát v BSE } \\
\text { Analýza }\end{array}$} & \multicolumn{12}{|c|}{ TIS-1 } \\
\hline & \multicolumn{4}{|c|}{ Svetlá zóna } & \multicolumn{4}{|c|}{ Prechodná zóna } & \multicolumn{4}{|c|}{ Tmavá zóna } \\
\hline & 1 & 2 & 3 & 4 & 5 & 6 & 7 & 8 & 9 & 10 & 11 & 12 \\
\hline $\mathrm{SiO}_{2}$ & 26.14 & 28.12 & 29.89 & 28.61 & 31.21 & 33.77 & 33.81 & 32.46 & 35.24 & 36.13 & 36.22 & 36.26 \\
\hline $\mathrm{TiO}_{2}^{2}$ & 12.34 & 9.90 & 7.75 & 9.44 & 6.32 & 3.69 & 3.72 & 4.74 & 1.88 & 0.38 & 0.16 & 1.32 \\
\hline $\mathrm{Al}_{2} \mathrm{O}_{3}$ & 2.82 & 3.10 & 3.39 & 3.26 & 3.92 & 4.82 & 4.92 & 4.74 & 6.99 & 5.99 & 5.46 & 9.67 \\
\hline $\mathrm{Fe}_{2} \mathrm{O}_{3}$ & 24.17 & 24.64 & 24.44 & 23.90 & 23.55 & 22.93 & 23.29 & 23.11 & 20.49 & 22.20 & 22.98 & 17.25 \\
\hline $\mathrm{FeO}$ & 0 & 0 & 0 & 0 & 0 & 0 & 0 & 0 & 0 & 0 & 0 & 0 \\
\hline $\mathrm{MnO}$ & 0 & 0 & 0.11 & 0.04 & 0.07 & 0 & 0.03 & 0.06 & 0.04 & 0.15 & 0.39 & 0 \\
\hline $\mathrm{MgO}$ & 0.24 & 0.22 & 0.17 & 0.23 & 0.19 & 0.20 & 0.16 & 0.19 & 0.15 & 0.17 & 0.24 & 0.16 \\
\hline $\mathrm{CaO}$ & 32.79 & 33.05 & 33.42 & 33.12 & 33.64 & 33.92 & 34.03 & 33.75 & 34.52 & 34.53 & 34.14 & 35.25 \\
\hline Suma & 98.50 & 99.03 & 99.17 & 98.60 & 98.90 & 99.33 & 99.96 & 99.05 & 99.31 & 99.55 & 99.59 & 99.91 \\
\hline $\mathrm{Si}^{4+}$ & 263 & 2.406 & 2.538 & 2.451 & 2.638 & 2.811 & 2.799 & 2.721 & 2.892 & 2.966 & 2.980 & 2.914 \\
\hline $\mathrm{Al}^{3+}$ & 0.288 & 0.313 & 0.339 & 0.329 & 0.362 & 0.189 & 0.201 & 0.279 & 0.108 & 0.034 & 0.020 & 0.086 \\
\hline $\mathrm{Fe}^{3+}$ & .449 & 0.281 & 0.123 & 0.220 & & & & & & & & \\
\hline Suma Z & 3.000 & 3.000 & 3.000 & 3.000 & 3.000 & 3.000 & 3.000 & 3.000 & 3.000 & 3.000 & 3.000 & 3.000 \\
\hline $\mathrm{Al}^{3+}$ & & & & & 0.029 & 0.284 & 0.279 & 0.189 & 0.568 & 0.545 & 0.509 & 0.829 \\
\hline $\mathrm{Ti}^{4+}$ & 804 & 0.637 & 0.495 & 0.608 & 0.402 & 0.231 & 0.232 & 0.299 & 0.116 & 0.023 & 0.010 & 0.080 \\
\hline $\mathrm{Fe}^{3+}$ & 1.124 & 1.304 & 1.435 & 1.320 & 1.494 & 1.435 & 1.450 & 1.454 & 1.261 & 1.363 & 1.415 & 1.037 \\
\hline $\mathrm{Fe}^{2+}$ & 0 & 0 & 0 & 0 & 0 & 0 & 0 & 0 & 0 & 0 & 0 & 0 \\
\hline $\mathrm{Mn}^{2+}$ & 0.031 & 0.028 & 0.022 & 0.029 & 0.005 & 0 & 0.002 & & & 0.010 & 0.027 & 0 \\
\hline $\mathrm{Mg}^{2+}$ & 0 & 0 & 0.008 & 0.003 & 0.024 & 0.025 & 0.020 & 0.024 & 0.018 & 0.021 & 0.029 & 0.019 \\
\hline Suma Y & 1.959 & 1.970 & 1.960 & 1.960 & 1.954 & 1.975 & 1.982 & 1.969 & 1.965 & 1.963 & 1.991 & 1.965 \\
\hline $\mathrm{Ca}^{2+}$ & 3.041 & 3.030 & 3.040 & 3.040 & 3.046 & 3.025 & 3.018 & 3.031 & 3.035 & 3.037 & 3.009 & 3.035 \\
\hline Suma X & 3.041 & 3.030 & 3.040 & 3.040 & 3.046 & 3.025 & 3.018 & 3.031 & 3.035 & 3.037 & 3.009 & 3.035 \\
\hline Almandín & 0 & 0 & 0 & 0 & 0 & 0 & 0 & 0 & 0 & 0 & 0 & 0 \\
\hline Pyrop & 0 & 0 & 0.26 & 0.10 & 0.78 & 0.82 & 0.66 & 0.78 & 0.59 & 0.68 & 0.95 & 0.62 \\
\hline Spessartín & 1.01 & 0.92 & 0.72 & 0.94 & 0.16 & 0 & 0.07 & 0.13 & 0.10 & 0.33 & 0.88 & 0 \\
\hline Grosulár & 4.85 & 3.88 & 4.72 & 4.82 & 6.57 & 17.25 & 16.28 & 13.13 & 31.72 & 31.23 & 28.43 & 44.52 \\
\hline Andradit & 54.88 & 63.96 & 70.11 & 64.45 & 72.88 & 70.57 & 71.55 & 71.30 & 61.89 & 66.64 & 69.25 & 50.93 \\
\hline Schorlomit & 39.26 & 31.25 & 24.19 & 29.69 & 19.61 & 11.36 & 11.45 & 14.66 & 5.69 & 1.12 & 0.49 & 3.93 \\
\hline
\end{tabular}

a)

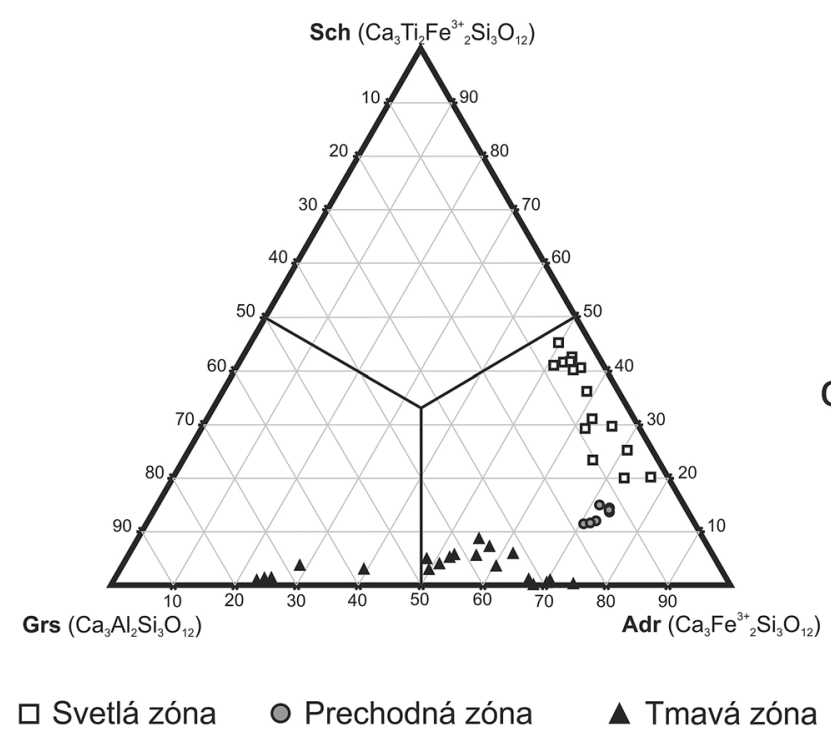

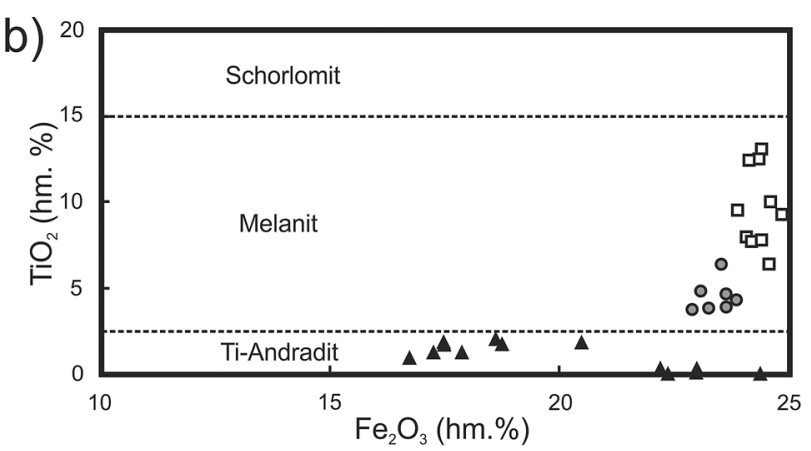

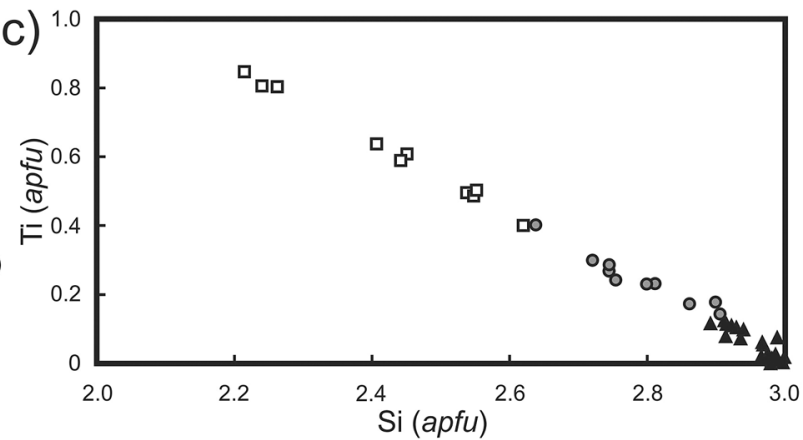

Obr. 5 Zobrazenie analyzovaných granátov z Tisovca: a) klasifikačný diagram podla Grew et al. (2013); b) diagram $\mathrm{TiO}_{2}$ verzus $\mathrm{Fe}_{2} \mathrm{O}_{3}$ (hm. \%) podla Brod et al. (2003); c) diagram Ti verzus Si (apfu). Poznámka: názov melanit sa používa na označenie variety Ti-obohateného andraditu. 
ných granátoch bola pozorovaná výrazná schorlomitová substitúcia ${ }^{\mathrm{Y}} \mathrm{R}^{4+}+{ }^{\mathrm{Z}} \mathrm{R}^{3+} \leftrightarrow{ }^{\mathrm{Z}} \mathrm{Si}+{ }^{\mathrm{Y}} \mathrm{R}^{3+}$, pričom platí že ${ }^{\mathrm{Y}} \mathrm{R}^{4+}=$ $\mathrm{Ti} ;{ }^{\mathrm{Y}} \mathrm{R}^{3+}=\mathrm{Fe}^{3+}, \mathrm{Al}^{3+} ;{ }^{\mathrm{Z}} \mathrm{R}^{3+}=\mathrm{Fe}^{3+}, \mathrm{Al}^{3+}$. Deficit $\mathrm{Si}$ v kryštalografickej pozícii $Z$ naznačuje prítomnost' hydrogranátovej substitúcie $\left(\mathrm{SiO}_{4}\right)^{4-} \leftrightarrow\left(\mathrm{O}_{4} \mathrm{H}_{4}\right)^{4-}$. Obsah $\mathrm{F}$ nebol analyzovaný, preto nie je možné stanovit' substitúciu $\mathrm{F}^{-} \leftrightarrow \mathrm{OH}^{-}$ v hydroxylovej skupine $\left[(\mathrm{OH}, \mathrm{F})_{4}\right]^{4-}$.

\section{Stručný opis minerálnej asociácie}

Klinopyroxény majú zloženie diopsidu (obr. 6) s pomerne vyrovnaným pomerom zastúpenia wollastonitovej a enstatitovej zložky (tab. 3). Obsah $\mathrm{Mg}^{2+}$ sa pohybuje v intervale 0.87 - 0.92 apfu a obsah $\mathrm{Fe}^{3+} 0.05-0.09$ apfu. Pomer $\mathrm{Mg} /(\mathrm{Mg}+\mathrm{Fe})$ vyjadrený ako $X_{\mathrm{Mg}}$ sa pohybuje $\mathrm{v}$ intervale 0.90 - 0.94. Prítomnost' chloritov bola len lokálna

Tabul'ka 2 Reprezentatívne mikrosondové analýzy granátov ( $\mathrm{hm}$. \%) vzorky TIS-2 v Ca-skarnoch prepočítané na 12 kyslíkov a 8 katiónov (apfu) s vyjadrením zastúpenia koncových členov (mol. \%).

\begin{tabular}{|c|c|c|c|c|c|c|c|c|c|c|c|c|}
\hline \multirow{3}{*}{$\begin{array}{l}\text { Vzorka } \\
\text { Granát v BSE } \\
\text { Analýza } \\
\end{array}$} & \multicolumn{12}{|c|}{ TIS-2 } \\
\hline & \multicolumn{4}{|c|}{ Svetlá zóna } & \multicolumn{4}{|c|}{ Prechodná zóna } & \multicolumn{4}{|c|}{ Tmavá zóna } \\
\hline & 1 & 2 & 3 & 4 & 5 & 6 & 7 & 8 & 9 & 10 & 11 & 12 \\
\hline $\mathrm{SiO}_{2}$ & 25.56 & 30.10 & 25.88 & 28.62 & 32.95 & 32.94 & 35.22 & 33.36 & 36.73 & 36.05 & 35.67 & 36.48 \\
\hline $\mathrm{TiO}_{2}$ & 13.00 & 7.88 & 12.38 & 9.18 & 4.29 & 4.56 & 2.83 & 3.88 & 1.25 & 1.88 & 2.05 & 1.73 \\
\hline $\mathrm{Al}_{2} \mathrm{O}_{3}$ & 2.75 & 3.53 & 3.03 & 3.13 & 4.64 & 4.59 & 8.15 & 5.11 & 8.08 & 9.05 & 8.05 & 9.08 \\
\hline $\mathrm{Fe}_{2} \mathrm{O}_{3}$ & 24.44 & 24.10 & 24.37 & 24.87 & 23.88 & 23.66 & 18.32 & 23.65 & 17.87 & 17.47 & 18.61 & 17.47 \\
\hline $\mathrm{FeO}$ & 0 & 0.01 & 0 & 0 & 0 & 0 & 0 & 0 & 0 & 0 & 0 & 0 \\
\hline $\mathrm{MnO}$ & 0 & 0 & 0 & 0 & 0.01 & 0 & 0 & 0.05 & 0 & 0.10 & 0.05 & 0.06 \\
\hline $\mathrm{MgO}$ & 0.22 & 0.14 & 0.23 & 0.19 & 0.15 & 0.17 & 0.27 & 0.17 & 0.17 & 0.21 & 0.19 & 0.22 \\
\hline $\mathrm{CaO}$ & 32.70 & 33.42 & 32.66 & 33.20 & 33.83 & 33.78 & 34.86 & 34.14 & 34.93 & 34.83 & 34.54 & 35.16 \\
\hline Suma & 98.67 & 99.18 & 98.55 & 99.19 & 99.75 & 99.70 & 99.65 & 100.36 & 99.03 & 99.59 & 99.16 & 100.20 \\
\hline $\mathrm{Si}^{4^{++}}$ & 2.215 & 2.552 & 2.240 & 2.442 & 2.744 & 2.744 & 2.862 & 2.754 & 2.989 & 2.914 & 2.911 & 2.929 \\
\hline $\mathrm{Al}^{3+}$ & .281 & 353 & 0.309 & 0.315 & 0.256 & 0.256 & 0.138 & 0.246 & 0.011 & 0.086 & 0.089 & 0.071 \\
\hline $\mathrm{Fe}^{3+}$ & 0.505 & 0.095 & 0.451 & 0.243 & & & & & & & & \\
\hline Suma Z & 3.000 & 3.000 & 3.000 & 3.000 & 3.000 & 3.000 & 3.000 & 3.000 & 3.000 & 3.000 & 3.000 & 3.000 \\
\hline $\mathrm{Al}^{3+}$ & & & & & 0.200 & 0.195 & 0.642 & 0.251 & 0.764 & 0.776 & 0.685 & 0.788 \\
\hline $\mathrm{Ti}^{4+}$ & 0.847 & 0.503 & 0.806 & 0.589 & 0.269 & 0.286 & 0.173 & 0.241 & 0.077 & 0.114 & 0.126 & 0.104 \\
\hline $\mathrm{Fe}^{3+}$ & 1.089 & 1.443 & 1.135 & 1.351 & 1.494 & 1.483 & 1.117 & 1.464 & 1.094 & 1.061 & 1.142 & 1.053 \\
\hline $\mathrm{Fe}^{2+}$ & 0 & 0.001 & 0 & 0 & 0 & 0 & 0 & 0 & 0 & 0 & 0 & 0 \\
\hline $\mathrm{Mn}^{2+}$ & 0.028 & 0.018 & 0.030 & 0.024 & 0.001 & 0 & 0 & 0.003 & 0 & 0.007 & 0.003 & 0.004 \\
\hline $\mathrm{Mg}^{2+}$ & 0 & 0 & 0 & 0 & 0.019 & 0.021 & 0.033 & 0.021 & 0.021 & 0.025 & 0.023 & 0.026 \\
\hline Suma Y & 1.964 & 1.964 & 1.971 & 1.965 & 1.981 & 1.985 & 1.965 & 1.981 & 1.955 & 1.983 & 1.980 & 1.976 \\
\hline $\mathrm{Ca}^{2+}$ & 3.036 & 3.036 & 3.029 & 3.035 & 3.019 & 3.015 & 3.035 & 3.019 & 3.045 & 3.017 & 3.020 & 3.024 \\
\hline Suma X & 3.036 & 3.036 & 3.029 & 3.035 & 3.019 & 3.015 & 3.035 & 3.019 & 3.045 & 3.017 & 3.020 & 3.024 \\
\hline Almandín & 0 & 0.03 & 0 & 0 & 0 & 0 & 0 & 0 & 0 & 0 & 0 & 0 \\
\hline Pyrop & 0 & 0 & 0 & 0 & 0.63 & 0.69 & 1.08 & 0.69 & 0.68 & 0.82 & 0.76 & 0.85 \\
\hline Spessartín & 0.91 & 0.59 & 0.98 & 0.78 & 0.03 & 0 & 0 & 0.10 & 0 & 0.23 & 0.10 & 0.13 \\
\hline Grosulár & 4.31 & 3.83 & 3.84 & 4.09 & 12.32 & 11.91 & 35.85 & 15.17 & 42.03 & 41.14 & 36.70 & 42.19 \\
\hline Andradit & 53.31 & 70.85 & 55.66 & 66.25 & 73.74 & 73.27 & 54.61 & 72.17 & 53.52 & 52.20 & 56.24 & 51.72 \\
\hline Schorlomit & 41.47 & 24.70 & 39.52 & 28.88 & 13.28 & 14.13 & 8.46 & 11.88 & 3.77 & 5.61 & 6.20 & 5.11 \\
\hline
\end{tabular}

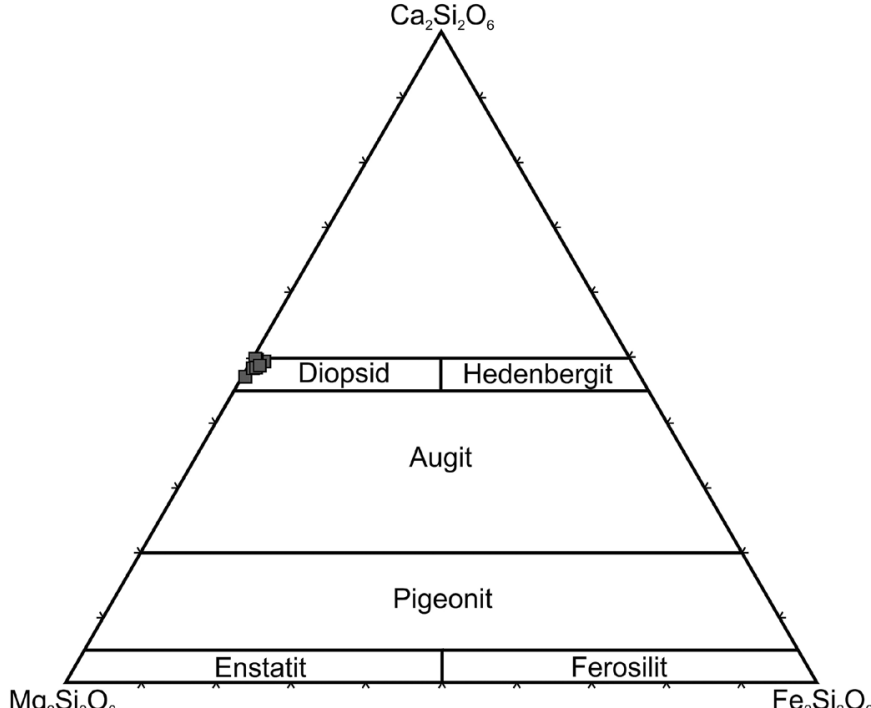

Obr. 6 Zobrazenie analyzovaných klinopyroxénov z Tisovca v klasifikačnom diagrame podla Morimoto et al. (1988). 
a indikuje, že vznikali počas retrográdnej etapy metamorfózy. Z hl'adiska chemického zloženia je zastúpený klinochlór s obsahom $\mathrm{Mg}^{2+} \mathrm{v}$ intervale 4.67 - 4.81 apfu a maximálna hodnota $X_{\mathrm{Mg}}$ dosahuje 0.97 (tab. 4). Analyzované kalcity sú z hl'adiska chemického zloženia homogénne a neobsahujú prímesi (tab. 5).

\section{Diskusia}

Kryštalochémii a zonálnosti Ti-obohatených andraditov sa venovali viacerí autori (napr. Armbruster et al. 1998; Agrosi et al. 2002; Antao et al. 2015). Vo všeobecnosti neexistuje jednotné pravidlo na klasifikáciu Ti-obohatených granátov. Klasifikácia podla Grew et al. (2013) vychádza z komplexných výsledkov viacerých autorov, pričom schorlomit $\mathrm{Ca}_{3}\left(\mathrm{Ti}_{1} \mathrm{Fe}^{3+}\right)_{2}(\mathrm{Si}, \mathrm{Fe})_{3} \mathrm{O}_{12}$ a morimotoit $\mathrm{Ca}_{3}\left(\mathrm{Ti}_{1} \mathrm{Fe}^{2+}, \mathrm{Fe}^{3+}\right)_{2}\left(\mathrm{Si}, \mathrm{Fe}^{3+}\right)_{3} \mathrm{O}_{12}$ sa považujú za jediné dva platné členy granátovej superskupiny obohatenej o titán. Existencia týchto členov nesplńa jednoznačný rozlišovací charakter a preto viacerí autori (Antao et al. 2015; Schingaro et al. 2016; Schmitt et al. 2019) nad'alej používajú označenie Ti-andradit (var. melanit) na odlíšenie andraditu výrazne obohateného o Ti, ktorý nespadá do schorlomitového alebo morimotoitového klasifikačného pol'a.
Podla Deer et al. (2013) musí schorlomit spíňat' podmienku ${ }^{\mathrm{Y} T i>} \mathrm{Y}^{\mathrm{F}} \mathrm{F}^{3+}$ (v oktaedrickej pozícii) čo je $v$ približnej zhode s $\mathrm{TiO}_{2}>15 \mathrm{hm}$. \%. Nami analyzované granáty dosahujú maximálne $13 \mathrm{hm}$. \% $\mathrm{TiO}_{2}$ a vo všetkých prevláda ${ }^{\mathrm{Y}} \mathrm{Fe}^{3+}>{ }^{\mathrm{Y}} \mathrm{Ti}$ preto ich klasifikujeme ako Ti-andradit, varieta melanit (tab. 1, 2; obr. 5b).

Maximálny obsah Ti (0.85 apfu) v analyzovaných granátoch zodpovedá granátom $z$ vápenato-silikátových kontaktných rohovcov z Minnesoty, ktoré publikoval Labotka (1995). Ti-andradity bývajú prítomné aj v metaultramafických horninách. $\mathrm{V}$ rodingite $\mathrm{z}$ Japonska bol identifikovaný zvýšený obsah titánu v andraditoch, ktorý dosahoval hodnotu 0.65 apfu (Schmitt et al. 2019). Zo Slovenska v rámci serpentinizovaného harzburgitu v Dobšinej bol prítomný andradit s maximálnou hodnotou Ti 0.39 apfu (Putiš et al. 2012).

$\checkmark$ poslednom období sa stále viac kladie dôraz na komplexné štúdium zonálnych granátov. Kompozičné variácie ovplyvňujúce charakter zonálnosti vznikajú počas špecifických kineticko-štruktúrnych podmienok rastu granátov $v$ rámci pôsobenia hydrotermálnych a metasomatických účinkov (Jamtveit et al. 1995; Ivanova et al. 1998; Zhai et al. 2014; Park et al. 2017; Ryan-Davis et al. 2019). Vplyv pôsobenia zdrojových hydrotermálnych

Tabul'ka 3 Reprezentatívne mikrosondové analýzy klinopyroxénov v Ca-skarnoch z Tisovca (hm. \%) prepočítané na 4 katióny (apfu) s vyjadrením zastúpenia koncových členov (mol. \%).

\begin{tabular}{|c|c|c|c|c|c|c|c|c|}
\hline Vzorka & & TIS & & & & & & \\
\hline Analýza & 1 & 2 & 3 & 4 & 1 & 2 & 3 & 4 \\
\hline $\mathrm{SiO}_{2}$ & 52.41 & 51.49 & 52.31 & 52.15 & 51.56 & 52.03 & 53.63 & 52.23 \\
\hline $\mathrm{TiO}_{2}$ & 0 & 0.02 & 0.29 & 0.02 & 0.03 & 0.06 & 0.03 & 0.05 \\
\hline $\mathrm{Al}_{2} \mathrm{O}_{3}$ & 1.21 & 1.70 & 2.37 & 0.89 & 0.81 & 1.29 & 1.17 & 0.85 \\
\hline $\mathrm{Fe}_{2} \mathrm{O}_{3}^{3}$ & 2.54 & 3.58 & 1.64 & 2.31 & 3.62 & 2.03 & 2.07 & 2.85 \\
\hline $\mathrm{FeO}$ & 1.02 & 0.22 & 0 & 0.62 & 0 & 0 & 0.34 & 0 \\
\hline $\mathrm{MnO}$ & 0.43 & 0.35 & 0.37 & 0.97 & 0.90 & 0.38 & 0.40 & 0.96 \\
\hline $\mathrm{MgO}$ & 15.86 & 15.87 & 17.06 & 15.73 & 15.56 & 16.78 & 17.02 & 16.08 \\
\hline $\mathrm{CaO}$ & 25.64 & 25.52 & 25.84 & 25.55 & 25.84 & 25.86 & 25.81 & 25.53 \\
\hline $\mathrm{Na}_{2} \mathrm{O}$ & 0.02 & 0 & 0.01 & 0 & 0 & 0.05 & 0 & 0.04 \\
\hline $\mathrm{K}_{2} \mathrm{O}$ & 0 & 0.01 & 0.01 & 0 & 0.01 & 0 & 0 & 0 \\
\hline Suma & 99.13 & 98.76 & 99.90 & 98.24 & 98.33 & 98.48 & 100.48 & 98.59 \\
\hline $\mathrm{Si}^{4+}$ & 1.939 & 1.912 & 1.885 & 1.947 & 1.927 & 1.902 & 1.946 & 1.941 \\
\hline $\mathrm{Al}^{3+}$ & 0.053 & 0.074 & 0.101 & 0.040 & 0.036 & 0.056 & 0.050 & 0.037 \\
\hline $\mathrm{Fe}^{3+}$ & 0.008 & 0.014 & 0.014 & 0.013 & 0.037 & 0.042 & 0.004 & 0.022 \\
\hline Suma & 2.000 & 2.000 & 2.000 & 2.000 & 2.000 & 2.000 & 2.000 & 2.000 \\
\hline $\mathrm{Ti}^{4+}$ & 0 & 0.001 & 0.008 & 0.001 & 0.001 & 0.002 & 0.001 & 0.001 \\
\hline $\mathrm{Fe}^{3+}$ & 0.063 & 0.087 & 0.065 & 0.051 & 0.068 & 0.056 & 0.052 & 0.059 \\
\hline $\mathrm{Mg}^{2+}$ & 0.875 & 0.878 & 0.917 & 0.876 & 0.867 & 0.914 & 0.921 & 0.891 \\
\hline $\mathrm{Fe}^{2+}$ & 0.032 & 0.007 & 0 & 0.019 & 0 & 0 & 0.010 & 0 \\
\hline $\mathrm{Mn}^{2+}$ & 0.013 & 0.011 & 0 & 0.031 & 0.028 & 0.012 & 0.012 & 0.030 \\
\hline Suma & 0.983 & 0.984 & 1.000 & 0.978 & 0.964 & 0.984 & 0.996 & 0.981 \\
\hline $\mathrm{Mn}^{2+}$ & 0 & 0 & 0.001 & 0 & 0 & 0 & 0 & 0 \\
\hline $\mathrm{Ca}^{2+}$ & 1.016 & 1.016 & 0.998 & 1.022 & 1.036 & 1.013 & 1.003 & 1.017 \\
\hline $\mathrm{Na}^{+}$ & 0.001 & 0 & 0.001 & 0 & 0 & 0.004 & 0 & 0.003 \\
\hline $\mathrm{K}^{+}$ & 0 & 0 & 0 & 0 & 0 & 0 & 0 & 0 \\
\hline Suma & 1.017 & 1.016 & 1.000 & 1.022 & 1.036 & 1.016 & 1.004 & 1.019 \\
\hline Wollastonit & 49.75 & 49.27 & 46.98 & 50.50 & 51.79 & 49.43 & 49.01 & 50.63 \\
\hline Enstatit & 45.18 & 45.96 & 47.60 & 44.95 & 44.92 & 47.16 & 47.29 & 45.98 \\
\hline Ferosilit & 1.63 & 0.35 & 0 & 1.00 & 0 & 0 & 0.54 & 0 \\
\hline Kanoit & 0.70 & 0.58 & 0.59 & 1.57 & 1.48 & 0.61 & 0.63 & 1.56 \\
\hline Ca-Tschermakit & 2.74 & 3.81 & 4.43 & 1.94 & 1.78 & 2.72 & 2.48 & 1.77 \\
\hline Ti-Tschermakit & 0 & 0.03 & 0.41 & 0.03 & 0.04 & 0.09 & 0.04 & 0.07 \\
\hline$X_{\mathrm{Mg}}$ & 0.96 & 0.99 & 1.00 & 0.98 & 1.00 & 1.00 & 0.99 & 1.00 \\
\hline
\end{tabular}


Tabul'ka 4 Reprezentatívne elektrónové mikroanalýzy chloritov (hm. \%) prepočítané na 14 kyslíkov (apfu). Symbol* vyjadruje dopočitanie $\mathrm{H}_{2} \mathrm{O}$ pre $\mathrm{OH}^{-}$.

\begin{tabular}{|c|c|c|c|}
\hline Vzorka & & IS-1 & \\
\hline Analýza & 1 & 2 & 3 \\
\hline $\mathrm{SiO}_{2}$ & 31.76 & 31.13 & 31.64 \\
\hline $\mathrm{TiO}_{2}$ & 0.03 & 0.06 & 0.14 \\
\hline $\mathrm{Al}_{2} \mathrm{O}_{3}$ & 19.78 & 19.87 & 19.78 \\
\hline $\mathrm{FeO}$ & 2.22 & 1.56 & 2.16 \\
\hline $\mathrm{MnO}$ & 0.08 & 0 & 0 \\
\hline $\mathrm{MgO}$ & 33.83 & 34.67 & 33.86 \\
\hline $\mathrm{CaO}$ & 0.21 & 0.11 & 0.22 \\
\hline $\mathrm{Na}_{2} \mathrm{O}$ & 0.03 & 0 & 0 \\
\hline $\mathrm{K}_{2} \mathrm{O}$ & 0.04 & 0 & 0.03 \\
\hline $\mathrm{H}_{2} \mathrm{O}^{*}$ & 12.95 & 12.90 & 12.94 \\
\hline Suma & 100.93 & 100.30 & 100.77 \\
\hline $\mathrm{Si}^{4+}$ & 2.941 & 2.894 & 2.934 \\
\hline${ }^{\mathrm{IV}} \mathrm{Al}^{3+}$ & 1.059 & 1.106 & 1.066 \\
\hline Suma T & 4.000 & 4.000 & 4.000 \\
\hline $\mathrm{Ti}^{4+}$ & 0.002 & 0.004 & 0.010 \\
\hline${ }^{\mathrm{V}} \mathrm{Al}^{3+}$ & 1.100 & 1.071 & 1.095 \\
\hline $\mathrm{Fe}^{2+}$ & 0.172 & 0.121 & 0.167 \\
\hline $\mathrm{Mn}^{2+}$ & 0.006 & 0 & 0 \\
\hline $\mathrm{Mg}^{2+}$ & 4.671 & 4.805 & 4.680 \\
\hline $\mathrm{Ca}^{2+}$ & 0.021 & 0.011 & 0.022 \\
\hline $\mathrm{Na}^{+}$ & 0.005 & 0 & 0 \\
\hline $\mathrm{K}^{+}$ & 0.005 & 0 & 0.004 \\
\hline Suma M & 5.982 & 6.013 & 5.978 \\
\hline $\mathrm{OH}^{-}$ & 8.000 & 8.000 & 8.000 \\
\hline Suma A & 8.000 & 8.000 & 8.000 \\
\hline$X_{\mathrm{Mg}}$ & 0.96 & 0.97 & 0.97 \\
\hline
\end{tabular}

Tabul'ka 5 Reprezentatívne mikrosondové analýzy kalcitu (hm. \%) prepočitané na sumu katiónov = 1 (apfu). Symbol * vyjadruje dopočitanie $\mathrm{CO}_{2}$.

\begin{tabular}{lrrrrrr}
\hline Vzorka & \multicolumn{3}{c}{ TIS-1 } & & \multicolumn{3}{c}{ TIS-2 } \\
\hline Analýza & 1 & 2 & 3 & 1 & 2 & 3 \\
\hline $\mathrm{FeO}$ & 0.21 & 0.11 & 0.19 & 0.06 & 0.23 & 0.15 \\
$\mathrm{MnO}$ & 0.02 & 0 & 0.03 & 0.07 & 0.03 & 0.08 \\
$\mathrm{MgO}$ & 0.07 & 0 & 0.06 & 0.08 & 0.05 & 0.05 \\
$\mathrm{CaO}$ & 55.74 & 55.61 & 55.41 & 55.36 & 56.00 & 55.79 \\
$\mathrm{CO}_{2}{ }^{*}$ & 44.06 & 43.86 & 43.68 & 43.75 & 44.39 & 44.00 \\
\hline $\mathrm{Suma}^{2}$ & 100.10 & 99.58 & 99.36 & 99.31 & 100.70 & 100.06 \\
\hline $\mathrm{Fe}^{2+}$ & 0.003 & 0.002 & 0.003 & 0.001 & 0.003 & 0.002 \\
$\mathrm{Mn}^{2+}$ & 0 & 0 & 0 & 0.001 & 0 & 0.001 \\
$\mathrm{Mg}^{2+}$ & 0.002 & 0 & 0.001 & 0.002 & 0.001 & 0.001 \\
$\mathrm{Ca}^{2+}$ & 0.995 & 0.998 & 0.995 & 0.996 & 0.995 & 0.996 \\
\hline $\mathrm{Suma}^{2+}$ & 1.000 & 1.000 & 0.999 & 1.000 & 0.999 & 1.000 \\
\hline $\mathrm{FeCO}_{3}$ & 0.34 & 0.18 & 0.31 & 0.10 & 0.37 & 0.24 \\
$\mathrm{MnCO}_{3}$ & 0.03 & 0 & 0.05 & 0.11 & 0.05 & 0.13 \\
$\mathrm{MgCO}_{3}$ & 0.15 & 0 & 0.13 & 0.17 & 0.10 & 0.10 \\
$\mathrm{CaCO}_{3}$ & 99.48 & 99.25 & 98.90 & 98.81 & 99.95 & 99.57 \\
\hline $\mathrm{Suma}^{2}$ & 100.00 & 99.43 & 99.38 & 99.18 & 100.47 & 100.05 \\
\hline & & & & & &
\end{tabular}

fluíd na distribúciou prvkov a tvorbu zonálnosti minerálov sa preferuje pri vzniku skarnových ložísk (Meinert et al. 2005; Fei et al. 2019; Yu et al. 2020).

Andraditová $\left(\operatorname{Adr}_{50.9-73.7}\right)$, grosulárová $\left(\mathrm{Grs}_{3.8-4.5}\right)$ a schorlomitová $\left(\mathrm{Sch}_{0.5-41.5}\right)$ zložka granátov vo vzorkách TIS-1 a TIS-2 sa variabilne strieda $v$ jednotlivých BSE kontrastných zónach. Zo slovenských lokalít máme niekol'ko publikovaných príkladov granátov grosulárovo -andraditového zloženia zo skarnov na lokalite Trohanka pri Prakovciach (Faryad, Peterec 1987) a Vyhne - Klokoč (Koděra, Chovan 1994). V andezitovom kameňolome Maglovec (Vyšná Šebastová) bol opísaný výskyt xenolitov Ca-skarnu, ktoré obsahujú granát grosulárovo-andraditového zloženia (Marcinčáková, Košuth 2011). Ružička et al. (2019) identifikovali zonálne granáty v brekciovitých rekryštalizovaných vápencoch z lokality Magnetový vrch, ktoré obsahovali $\mathrm{Grs}_{71-95}$ a $\mathrm{Adr}_{5-28}$

Šamajová $(1966,1972)$ v granátoch pochádzajúcich z tisoveckých skarnov pozorovala oscilačnú chemickú zonálnost' spolu s optickou anizotropiou, ktorú podl'a nej spôsobuje prevaha grosulárovej zložky. Na druhej strane Bacsó (1973) tvrdí, že anomálna anizotropia granátov je spôsobená nižšou teplotou ich vzniku. Prejavy opticky anomálnej anizotropie $v$ nami analyzovaných granátoch neboli pozorované.

\section{Záver}

Detailný výskum zonálnych granátov bol zameraný na identifikáciu rozdielov v ich chemickom zložení s ciel’om objasnit' substitučné vzt'ahy hlavných prvkov. $V$ analyzovaných granátoch celkový heterogénny charakter zonáInej stavby súvisí s fluidným režimom metasomatických procesov, ktorý mal zásadný vplyv na transfer prvkov počas kontaktnej metamorfózy. $\mathrm{V}$ analyzovaných granátoch sa strieda zastúpenie andraditovej, grosulárovej a schorlomitovej zložky $v$ jednotlivých zónach: 1 . svetlá zóna $\left(\operatorname{Adr}_{53.3-70.9} \mathrm{Sch}_{24.2-41.5} \mathrm{Grs}_{3.8-4.9}\right) ; 2$. prechodná zóna $\left(\operatorname{Adr}_{54.6-73.7} \mathrm{Grs}_{6.6-35.9} \mathrm{Sch}_{8.5-19.6}\right)$; 3. tmavá zóna ( $\mathrm{Adr}_{50.9-69.3}$ $\mathrm{Grs}_{28.4-44.5} \mathrm{Sch}_{0.5-6.2}$ ).

Z hl'adiska zonálnosti podla zobrazenia v BSE režime svetlá zóna obsahuje maximálne hodnoty $\mathrm{Ti} v$ intervale 0.50 - 0.85 apfu, ktoré postupne klesajú $\vee$ prechodnej zóne (0.17 - 0.40 apfu) až do minimálnych hodnôt v tmavej zóne (0.01 - 0.13 apfu). Bola potvrdená lineárna závislost' substitučného trendu medzi Si a Ti. Analyzované granáty sú súčast'ou minerálnej asociácie Ca-skarnov, ktorú tvorí diopsid, klinochlór a kalcit.

Substitúcie hlavných prvkov $v$ granátoch sú signifikantným znakom pri genetických interpretáciách. Zmeny hydrotermálneho fluidného režimu súvisiaceho $s$ pulzujúcim prínosom a regulovanou migráciou prvkov v rámci pôsobenia rôznej intenzity metasomatických účinkov kontaktnej metamorfózy sa odzrkadl'ujú v kompozičných zmenách, čo malo priamy dopad na heterogénnu tvorbu zonálnej stavby počas rastu granátov. Vytvorený bariérový efekt zonálnosti, pozorovaný v BSE režime ako kontrastné kompozičné rozhranie, je toho dôkazom. Pokračovanie rastu granátov je spojené so zmenou zloženia a tvorbou kontrastne odlišnej prechodnej zóny. Finálne štádium reprezentuje prevažne oscilačná zonálnost' kopírujúca línie kryštálovej symetrie s rôznou intenzitou zachovania na okrajoch granátových zŕn. Zonálnost' granátov v Ca-skarnoch z oblasti Magnetový vrch pri Tisovci nám poskytuje informáciu o variabilne pôsobiacich podmienkach, ktoré prebiehali počas prográdnej etapy metasomatických účinkov kontaktnej metamorfózy. 


\section{Pod'akovanie}

Vyslovujeme pod'akovanie recenzentom článku za podnetné pripomienky, ktoré prispeli k skvalitneniu rukopisu. Táto práca bola podporovaná Agentúrou na podporu výskumu a vývoja na základe zmluvy č. APVV-19-0065 a grantom VEGA 1/0151/19.

\section{Literatúra}

ADAM L', PTÁK J, ŠALÁt J (1956) Zpráva o geologickom mapovaní územia severozápadne od Tisovca vzhl'adom na rudný výskyt na vrchu Magnetová. Geol Práce Zpr 9: $120-123$

Agrosi G, Schingaro E, Pedrazzi G, Scandale E, Scordari $F$ (2002) A crystal chemical insight into sector zoning of a titanian andradite ('melanite') crystal. Eur J Mineral 14: 785-794

Antao SM, Mohib S, Zaman M, Marr RA (2015) Ti-rich andradites: Chemistry, structure, multi-phases, optical anisotropy, and oscillatory zoning. Canad Mineral 53: 1, 133-158

Armbruster T, Birrer J, Libowitzky E, Beran A (1998) Crystal chemistry of Ti-bearing andradites. Eur $\mathrm{J}$ Mineral 10: $907-921$

BAcsó Z (1959) Ložisko skarnového typu pri Tisovci (veporidy). Diplomová práca. MS, Geofond - archív ŠGÚDŠ, Bratislava, $61 \mathrm{~s}$

Bacsó Z (1964) Potriasové skarnové ložiská pri Tisovci. Geol Práce Zpr 31: 13-45

BAcsó Z (1973) Vznik potriasového skarnového ložiska pri Tisovci. Rigorózna práca. MS, Geofond - archív ŠGÚDŠ, Bratislava, $115 \mathrm{~s}$

Brod JA, Junqueira-Brod TC, Gaspar JC, Gibson SA, THompson RN (2003) Ti-rich and Ti-poor garnet from the Tapira carbonatite complex, SE Brazil: fingerprinting fractional crystallization and liquid immiscibility. In 8th International Kimberlite Conference, Abstracts, $1-5$

Deer WA, Howie RA, Zussman J (2013) An Introduction to the Rock-Forming Minerals. Mineralogical Society of Great Britain and Ireland, 498

Faryad SW, Peterec D (1987) Manifestations of skarn mineralization in the eastern part of the Spišsko-gemerské rudohorie Mts. Geol Zbor Geol Carpath 38, 1: 111-128

Fei X, Zhang Z, Cheng Z, Santosh M (2019) Factors controlling the crystal morphology and chemistry of garnet in skarn deposits: A case study from the Cuihongshan polymetallic deposit, Lesser Xing'an Range, NE China. Am Mineral 104: 1455-1468

Grew ES, Locock AJ, Mills SJ, Galuskina IO, Galuskin EV, HÁLENIUS U (2013) Nomenclature of the garnet supergroup. Am Miner 98: 785-811

IVanova TI, Shtukenberg AG, Punin YO, Frank-KameNETSKAYA OV, Sokolov PB (1998) On the complex zonality in grandite garnets and implications. Mineral Mag 62: 6, 857-868

JamtVeit B, RagnarsdottiR KV, Wood BJ (1995) On the origin of zoned grossular-andradite garnets in hydrothermal systems. Eur J Miner 7: 1339-1410

JunghANN H (1912) Das Eruptivgebiet von Tiszolcz (Comitat Gömör, Ungarn). N Jb Miner Beil Bd 33, Bonn

KLINEC A (1976) Geologická mapa Slovenského rudohoria (stred) a Nízkych Tatier (východ) 1: 50 000. ŠGúDŠ, Bratislava
KodĚra P, Chovan M (1994) Mineralogickoparagenetické pomery skarnového ložiska Vyhne - Klokoč. Miner Slov 26: 1, 38-49

KoneČnÝ V, LeXa J, Šımon L, Dublan L (2001) Neogénny vulkanizmus stredného Slovenska. Miner Slov 33: 3, 159-178

KoneČnÝ P, KoneČnÝ V, Kubeš P (2011) Paleovulkanická rekonštrukcia veporského stratovulkánu. Čiastková správa k záverečnej správe geologickej úlohy: Aktualizácia geologickej stavby problémových území Slovenska v mierke 1:50 000. MS, Geofond - archív ŠGÚDŠ, Bratislava: $235 \mathrm{~s}$

KoneČnÝ V, KoneČnÝ P, KuBeš P, PÉcskay Z (2015) Paleovolcanic reconstruction of the Neogene Vepor stratovolcano (Central Slovakia), part I. Miner Slov 47, 1: 1-76

LABOTKA TC (1995) Evidence for immiscibility in Ti-rich garnet in a calc-silicate hornfels from northeastern Minnesota. Am Mineral 80: 1026-1030

MARCINČÁKOVÁ Z, KoŠUtH M (2011) Characteristics of xenoliths in the East Slovakian Neogene Volcanites. Analele Stiintifice ale Universitatii "Al. I. Cuza" din Iasi Seria Geologie 57: 1, 17-27

MAZÚR E, LUKNIŠ M (1980) Geomorfologické jednotky (mapa 1: 500 000). Mazúr E, Jakál J (eds) Atlas SSR. SAV a Slov. úrad geod. a kart., Bratislava: 54-55

Meinert LD, DipPle GM, Nicolescu S (2005) World skarn deposits. In: Hedenduist JW, Thompson JFH, Goldfarb RJ, RICHARDS JP (eds.) Economic geology 100th Anniversary Volume 1905-2005. Elsevier Science BV, Amsterdam, 299-336

Morimoto N, Fabries J, Ferguson AK, Ginzburg IV, Ross M, Seifert FA, Zussman J (1988) Nomenclature of pyroxenes. Am Mineral 73: 1123-1133

Park C, Chol W, Kim H, Park M-H, Kang I-M, Lee H-S, SoNG Y (2017) Oscillatory zoning in skarn garnet: implication for tungsten ore exploration. Ore Geol Rev 89: 1006-1018

Putiš M, Koppa M, Snárska B, Koller F, Uher P (2012) The blueschist-associated perovskite-andradite-bearing serpentinized harzburgite from Dobšiná (the Meliata Unit), Slovakia. J Geosci 57: 4, 221-240

RuŽıČKA P, BAČík P, MıKUŠ T, MıLovSKÁ S (2019) Grosulár a vesuvianit $v$ brekciovitých rekryštalizovaných vápencoch z lokality Magnetový vrch pri Tisovci (Slovenská republika). Bull Mineral Petrolog 27(1): 72-81

Ryan-Davis J, Lackey JS, Gevedon M, Barnes JD, Lee C-TA, KITAJIMA K, VALLEY JW, (2019) Andradite skarn garnet records of exceptionally low $\delta^{18} \mathrm{O}$ values within an Early Cretaceous hydrothermal system, Sierra Nevada, CA. Contrib Mineral Petrol 174: 68, 1-19

Schingaro E, Lacalamita M, Mesto E, Ventruti G, Pedrazzi G, OtTOLINI L, ScordarI F (2016) Crystal chemistry and light elements analysis of Ti-rich garnets. Am Mineral 101: 371-384

Schmitt AC, Tokuda M, Yoshiasa A, Nishiyama T (2019) Titanian andradite in the Nomo rodingite: Chemistry, crystallography, and reaction relations. J Mineral Petrol Sci 114: 111-121

ŠAMAJOVÁ E (1966) Granate der kontakt-metasomatischen Lagerstätte bei Tisovec. Geol Sbor Geol Carpath 17: $2,223-235$

ŠAMAJOVÁ E (1972) Anisotrope Granate aus der Skarn-Lagerstätte bei Tisovec. Acta geol geogr Univ Comen Geol 22: 187-197 
VOJTKO R (2000) Are there tectonic units derived from the Meliata-Hallstatt trough incorporated into the tectonic structure of the Tisovec karst? (Muráň karstic plateau, Slovakia). Slovak Geol Mag 6, 4: 335-346

Yu F, Shu Q, Niu X, XING K, LI L, Lentz DR, Zeng Q, Yang W (2020) Composition of garnet from the Xianghualing skarn Sn deposit, south China: its petrogenetic significance and exploration potential. Minerals 10, 456: $1-17$
Zhal DG, LIU J J, Zhang HY, WANg JP, Su L, YANG XA, Wu $\mathrm{SH}$ (2014) Origin of oscillatory zoned garnets from the Xieertala Fe-Zn skarn deposit, northern China: In situ LA-ICP-MS evidence. Lithos 190-191: 279-291 